\title{
Relationship between CD 163 Tumor-Associated Macrophages and Colorectal-Cancer Stem Cell Markers
}

\author{
Imelda Rey ${ }^{1 *}$, Agung Putra ${ }^{2,3,4}$, Dharma Lindarto ${ }^{1,3}$, Fauzi Yusuf ${ }^{3,5}$ \\ ${ }^{1}$ Department of Internal Medicine, Medical Faculty, Universitas Sumatera Utara, 2015 Medan, Indonesia; ${ }^{2}$ Stem Cell And \\ Cancer Research, Medical Faculty, Sultan Agung Islamic University (UNISSULA), 50112 Semarang, Indonesia; ${ }^{3}$ Doctoral \\ Department of Medicine Science, Medical Faculty, Universitas Sumatera Utara, 20155 Medan, Indonesia; ${ }^{4}$ Department of \\ Pathology Anatomy, Medical Faculty, Sultan Agung Islamic University (UNISSULA), 50112 Semarang, Indonesia; ${ }^{5}$ Department \\ of Internal Medicine, Medical Faculty, Syiah Kuala Univeristy, 23111 Banda Aceh, Indonesia
}

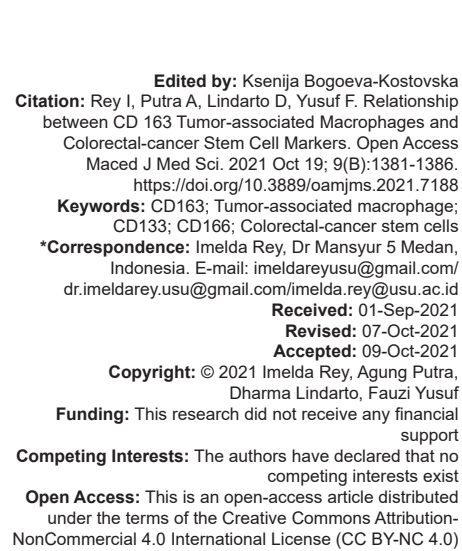

Introduction

Colorectal cancer $(\mathrm{CRC})$ is one of the most frequently diagnosed cancers, worldwide, with $1,360,600$ clinically diagnosed new cases [1]. Epidemiology studies have revealed that approximately $25 \%$ of all patients who undergo colonoscopies are diagnosed with CRC [2]. The resistance and recurrence of $\mathrm{CRC}$ against most therapeutic options may be due to the existence of cancer stem cells (CSCs) in CRC tumors (CR-CSCs), which express multidrug resistance (MDR) pumps at high levels [3]. Although most standard cytotoxic therapies target rapidly dividing tumor cells, CSCs divide less frequently than other cancer cells, rendering them less susceptible to chemotherapeutic agents [4]. CSCs represent a small population of cancer cells that possess the characteristics of self-renewal and pluripotency and are responsible for the initiation and maintenance of tumors, including the development of metastatic tumors [5]. Various surface markers have been identified among the CR-CSCs population, particularly CD133 and CD166. Several factors have been associated with the activation of CSCs into tumor tissue, particularly tumor-associated macrophages (TAMs) [6].

TAMs are polarized type-2 macrophages that express a 130-kDa glycoprotein with an aminoterminal signaling element anda 9 scavenger receptor cysteine-rich (SRCR) domains [7]. Epidemiological studies have reported that TAMs, in most tumors, promote the development of aggressive tumors, with high metastatic potential, that are associated with poor prognoses [8]. TAMs are characterized by CD163 expression have been found near CSCs, where they are thought to orchestrate various aspects of cancer, particularly during tumor invasion and metastasis [9]. A previous study reported the role played by TAMs during CRC-associated inflammation, in which TAMs activate CSCs to initiate tumor formation and the development of anti tumor drug resistance [6]. These studies suggested that tumor cells may be regulated by 
the M2-macrophage-mediated release of inflammatory mediators [9]. Macrophages may become polarized into an 'M2-like'state, with several features of M2 cells [10]. The diversity of M2 macrophages can enhance the progression of tumors and metastasis [11].

The existence of TAMs in tumors may support the activation of CSC characteristics [12], [13]. A high degree of TAM infiltration in tumors has been associated with poorer prognoses in cancer patients [14]. The previous studies have reported that CRC enrichment can have a negative impact on CRC prognosis [15], [16] and may represent an independent predictor of survival among CRC patients [17]. Infiltrating TAMs are always distributed near CR-CSCs and the number of TAMs has been positively correlated with the histological grade of the malignancy and the number of CSCs. The existence of TAMs existence has beenconsidered to be closely related to CSCs [18], [19]. However, whether association sexist between the expression levels of TAMs genes and those in CR-CSCs remains unclear. The aim of this study was to investigate the association between the expression of CD163 in TAMs and the expression of proteins in CR-CSCs, including CD133 and CD166, in CRC patients.

\section{Material and Methods}

\section{Patients and clinicopathological data}

This study used a cross-sectional design that was approved by the Faculty of Medicine, Universitas Sumatera Utara, Adam Malik General Hospital Ethical Committee Board (533/TGL/KEPK FK USU-RSUP $\mathrm{HAM} / 2018)$. We enrolled 118 patients, who were diagnosed with CRC, from September 2018 until July 2019. We collected the clinicopathological data, including gender, age, laboratory parameters, histological grading, and TNM stagings. The inclusion criteria for this study were primary colorectal adenocarcinoma and willingness to participate in the study, whereas the only exclusion criterion was a family history of CRC.

\section{method \\ Immunohistochemical (IHC) staining}

The specimens were formalin-fixed and paraffin-embedded, sliced at a 4- $\mu \mathrm{m}$ thickness and stained with hematoxylin and eosin to histopathologically diagnose CRC. We utilized IHC staining for the examination of CD133, CD166, and CD163 marker expression in TAMs. To analyze the expression levels of these marker proteins, we used a primary anti-CD133 antibody, GTX100567 [C1C2], Internal [1:100-1:1000] (GeneTex International Corporation, California, USA), a primary anti-CD166 antibody,
GTX83191 [10F1G12, 1:200-1:1000] (GeneTex International Corporation, California, USA), and a primary anti-CD163 antibody, GTX42365 [EDHu-1] (GeneTex International Corporation, California, USA). CD133, CD166, and CD163 expression levels were evaluated by two pathologists who did not have the patients' clinical information. An immunoreactivity score was calculated from the sum of both quantitative and qualitative parameters. A total score of $0-3$ indicated low-level expression, whereas a total score of 4-6 indicated high-level expression.

For the quantitative analysis, the following scoring system, relative to the percentage of immunoreactive cells ( $\%$ of the total area), was adopted, as previously described. Briefly, the percentages of immunoreactive cells were scored as follows: $0(0 \%$ immunoreactive cells); 1 (<10\% immunoreactive cells), 2 (10\%-50\% immunoreactive cells)' and 3 (more than $50 \%$ immunoreactive cells). For the qualitative analysis, the immunoreactive staining intensity was classified according to the following scores: 0 (no immunoreactivity), 1 (weak immunoreactivity), 2 (intermediate immunoreactivity), and 3 (strong immunoreactivity). A combined score of $<4$, after the quantitative. and qualitative analysis scores were added together, was considered to be "low-level" [20]. For the qualitative analysis of staining intensity, "strong" staining reflected intense staining similar to that observed for the positive control of the respective antibody. Figures 1 and 2 show high- and low-level CD 163 expression, respectively, as assessed by IHC staining in CRC samples. Figures 3 and 4 show high level of CD133 and CD166 expression respectively.

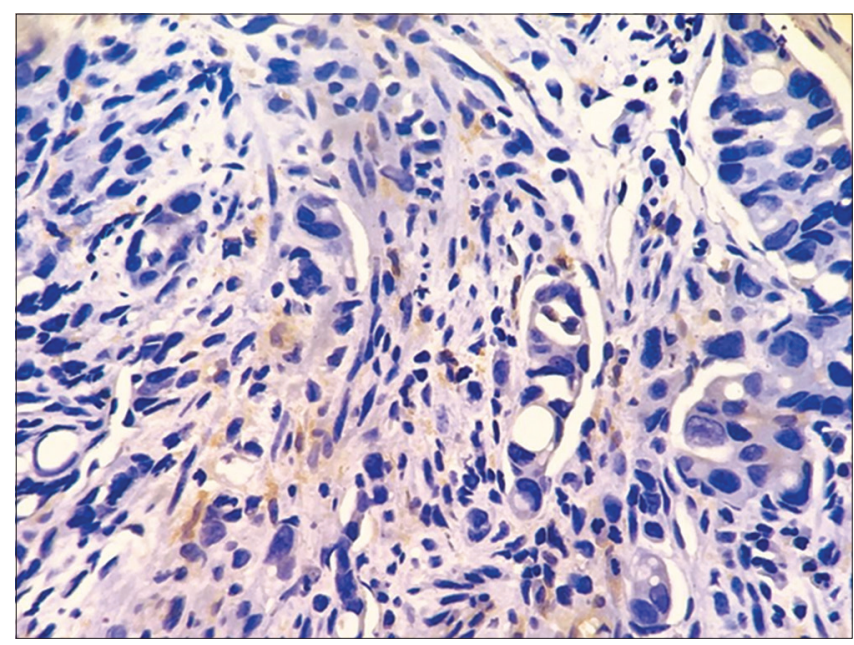

Figure 1: Immunohistochemical staining for CD163 in colorectal cancer samples. Low-level CD163 immunoreactivity appears as a light-brown color in the cytoplasm (red arrow), 400x magnification

\section{Statistical analysis}

Quantitative variables are presented as the mean \pm standard deviation (SD) or as the median (minimum-maximum), for normal and abnormal distributions, respectively. The chi-squared test was 
used for comparisons between CD163 expression levels in TAMs andCD133 and CD166 expression levels in CR-CSCs. For statistical analyses, we considered $p<0.05$ to be significant.

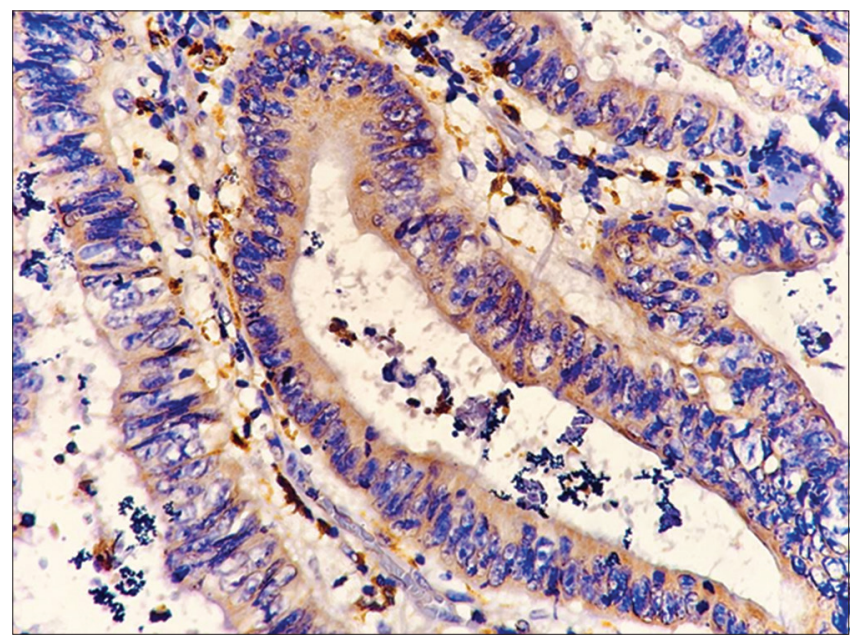

Figure 2: Immunohistochemical staining for CD163 in colorectal cancer samples. High-level CD163 immunoreactivity appears as a dark brown color in the cytoplasm (red arrow), 400x magnification

\section{Results}

The mean age of included patients was 57.17 \pm 12.99 years old. Of the 118 total CRC patients, $69(58.5 \%)$ were males and $49(41.5 \%)$ were females. CD163 expression levels are shown in Figures 1 and 2. The characteristics of all subjects are presented in Table 1. No significant differences were observed between high-level and low-level CD163 expression, based on gender, age, or laboratory parameters, as shown in Table 2.

Table 1: Baseline characteristics of subjects

\begin{tabular}{ll}
\hline Variable & $\mathrm{n}(\%)$ \\
\hline Gender & $69(58.5 \%)$ \\
$\quad$ Male & $49(41.5 \%)$ \\
Female & $57.30 \pm 12.99$ \\
Age (years) & \\
CD166 expression & $45(38.1 \%)$ \\
$\quad$ High-Level & $73(61.9 \%)$ \\
$\quad$ Low-Level & $44(37.3 \%)^{\text {a }}$ \\
CD133 expression & $74(62.7 \%)^{\mathrm{a}}$ \\
$\quad$ High-Level & \\
$\quad$ Low-Level & $43(36.4 \%)^{\mathrm{a}}$ \\
CD163 expression & $75(63.6 \%)^{\mathrm{a}}$ \\
$\quad$ High-Level & \\
$\quad$ Low-Level &
\end{tabular}

The comparisons between CD163 expression levels and those for CD133 and CD166 are shown in Tables 3 and 4, respectively. High-level CD163

Table 2: Comparisons of clinical and laboratory variables according to the CD163 expression level

\begin{tabular}{llll}
\hline Variable & \multicolumn{2}{l}{ CD163 } & p-value \\
\cline { 2 - 3 } & High-level & Low-level & \\
\hline Age (years) & $55.56 \pm 13.56$ & $58.29 \pm 12.63$ & 0.273 \\
Gender (Male: Female ) & $28: 15$ & $41: 34$ & 0.268 \\
Hb (gr/dl) & $10.37 \pm 1.97$ & $10.59 \pm 2.18$ & 0.594 \\
Leucocytes $\left(\times 10^{3} \mathrm{cells} / \mathrm{mm}^{3}\right)$ & $8.5(1.6-18.6)$ & $9.38(4.1-34.18)$ & 0.832 \\
Platelets $\left(\times 10^{3} \mathrm{cells} / \mathrm{mm}^{3}\right)$ & $317.6 \pm 125$ & $298.1 \pm 104.9$ & 0.369 \\
\hline
\end{tabular}

expression in TAMs increased was associated with a 2.770-fold increase in the risk of high-level CD133 expression and with a 2.616-fold increase in the risk of high-level CD166 expression. There are no significant association between CD163 TAM and CRC histological grading nor TNM staging (Tables 5 and 6 ).

Table 3: Comparisons between CD133 and CD163 expression levels

\begin{tabular}{lllll}
\hline & CD133 & & p-value & PR $(95 \% \mathrm{Cl})$ \\
\cline { 2 - 3 } & High-level & Low-level & & \\
\hline CD163 & & & & \\
$\quad$ High-level & $27(62.8 \%)$ & $16(37.2 \%)$ & $<0.001$ & $2.770(1.719-4.464)$ \\
Low-level & $17(22.7 \%)$ & $58(77.3 \%)$ & & \\
\hline
\end{tabular}

\section{Discussion}

TAMs play an important role in the regulation of the tumor microenvironment and the maintenance of the CSC niche [21]. TAM scan increase tumor growth by supporting angiogenesis, tumor progression, invasion, and metastasis [22]. CR-CSCs represent asmall population of $\mathrm{CR}$ cells that are characterized by the expression of CD133 and CD166. CD133, also known as prominin-1 is a five-transmembrane glycoprotein primarily localized in membrane protrusions [23], which impacts the development of radiochemotherapy resistance in CRCs [24]. CD166 an important CSC marker, functionally involved in cellcell interactions, T-cell proliferation, hematopoiesis, and angiogenesis [24], [25]. CD163 is a characteristic TAM protein that acts as the scavenger receptor for the hemoglobin $(\mathrm{Hb})$-haptoglobin complex [26]. In this study, we investigated the association between CD163 expression in TAMs and the expression of several CSC markers that have previously been reported to impact CRC prognosis, including CD133 and CD166.

Table 4: Comparisons between CD166 and CD163 expression levels

\begin{tabular}{|c|c|c|c|c|}
\hline & \multicolumn{2}{|l|}{ CD166 } & \multirow[t]{2}{*}{$p$-value } & \multirow[t]{2}{*}{ PR $(95 \% \mathrm{Cl})$} \\
\hline & High-level & Low-level & & \\
\hline \multicolumn{5}{|l|}{ CD163 } \\
\hline High-level & $27(62.8 \%)$ & $16(37.3 \%)$ & $<0.001$ & $2.616(1.645-4.160)$ \\
\hline Low-level & $18(24 \%)$ & $57(76 \%)$ & & \\
\hline
\end{tabular}

We found significant correlations between both high-level and low-level CD163 expression, and the expression levels of both CD 133 and CD 166 ( $p<0.001 ;$ PR [95\% confidence interval $(\mathrm{Cl})]=2.770$ [1.719-4.464]; $p<0.001 ;$ PR $[95 \%$ Cl] = 2.616 [1.6454.160], respectively). These results indicate that TAMs play an important role in the maintenance of CR-CSCs and can influence the expression of characteristic CSC marker proteins. The mechanism through which TAMs support CR-CSCs may involve the release of several growth factors and cytokines, such as interleukin (IL)-6, which activates and increases the stem-cell properties CR-CSCs [27]. This possibility is supported by a previous study showing the mutual cooperation between 
CR-CSCs and TAMs, during which CR-CSCs release chemoattractant molecules, such as chemokine ligand 2 (CCL2), CCL5, and vascular endothelial growth factor (VEGF)-A, to promote the infiltration of macrophages and encourage their polarization into an M2 phenotype [28]. In contrast, TAMs express growth factors that activate CSCs, leading to tumor formation and the development of antitumor drug resistance [29]. Furthermore, these interactions may stimulate the secretion of plateletderived growth factor (PDGF)-BB, inducing the activation of stromal cells, which secrete fibroblast growth factor (FGF)7 and FGF9 for CSC proliferation [30].

Table 5: CD 163 expression levels based on histological grade

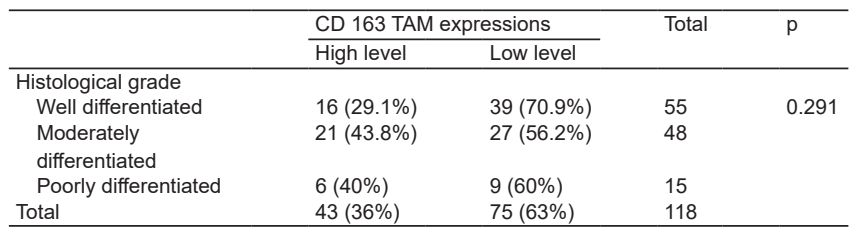

TAMs also express milk-fat globule epidermal growth factor VIII (MFG-E8), which is involved in angiogenesis, phagocytosis, and immune tolerance. MFG-E8 induces CSCs to form tumors and promotes antitumor drug resistance via the signal transducer and activator of transcription (STAT) 3 and hedgehog signaling pathways [31]. The absolute number of macrophages and the balance between activating and suppressing macrophages can influence tumor behavior. A low number of intra tumoral type 2 and a high number of activating type 1 macrophages have been correlated with reduced cancer recurrence and liver metastasis, which can be used to predict cancer prognosis [32].

In this study, we also found no differences in $\mathrm{Hb}$ levels between patients with high- and low-level CD163 expression. We did not classify decreases in $\mathrm{Hb}$ levels based on anemia grades or the time span of anemia. Severe, chronic anemia can lead to hypoxic tissues, which may induce the activation of CSCs, and TAM scan also be affected by hypoxia-related factors. Hypoxia may decrease TAM mobility and increase the number of TAMs found in tumors [33]. TAMs are involved in DNA damage and cancer-related inflammation, through the release of inflammatory mediators, such as IL-6 and tumor necrosis factor (TNF) $\alpha$ [34]. The release of cytokines, such as IL- 6 and TNF- $\alpha$, by TAMs may affect tumor cell invasion and stromal cells [35], [36], [37].

Table 6: CD 163 expression levels based on TNM stagings

\begin{tabular}{cllll}
\hline & \multicolumn{2}{l}{ CD 163 TAM expressions } & Total & $\mathrm{p}$ \\
\cline { 2 - 3 } & High level & Low level & & \\
\hline TNM staging & $13(25.5 \%)$ & $38(74.5 \%)$ & & \multirow{2}{*}{$0.079^{*}$} \\
Stage 1 & $6(42.9 \%)$ & $8(57.1 \%)$ & & \\
Stage 2 & $17(40.5 \%)$ & $25(59.5 \%)$ & & \\
Stage 3 & $7(63.6 \%)$ & $4(36.4 \%)$ & & \\
Stage 4 & $43(36.4)$ & $75(63.6 \%)$ & 118 & \\
Total & & &
\end{tabular}

Tumor histological grade might be considered to be corelated with TAMs functions. A previous study reported that the more malignant the histopathology fenotipe associated with macrophage infiltration and extensive stromal reactions in CRC [38]. There was significant association of TAMs density and histological grade [39], [40], [41]. In this study, we didn't find significant association of CD163 TAMs and CRC histological grade $(p=0.291)$. The difference results might be due to the marker that used for TAMs were different such as CD 68, meanwhile in this study we used CD 163 as TAMs marker. In this study, we also didn't find any significant association of CD 163 TAM and TNM stagings. This finding was similar to the previous studies that didn't find association among these [40], [42], [43].

One limitation of this study was that we did not assess the levels of other inflammatory factors, such

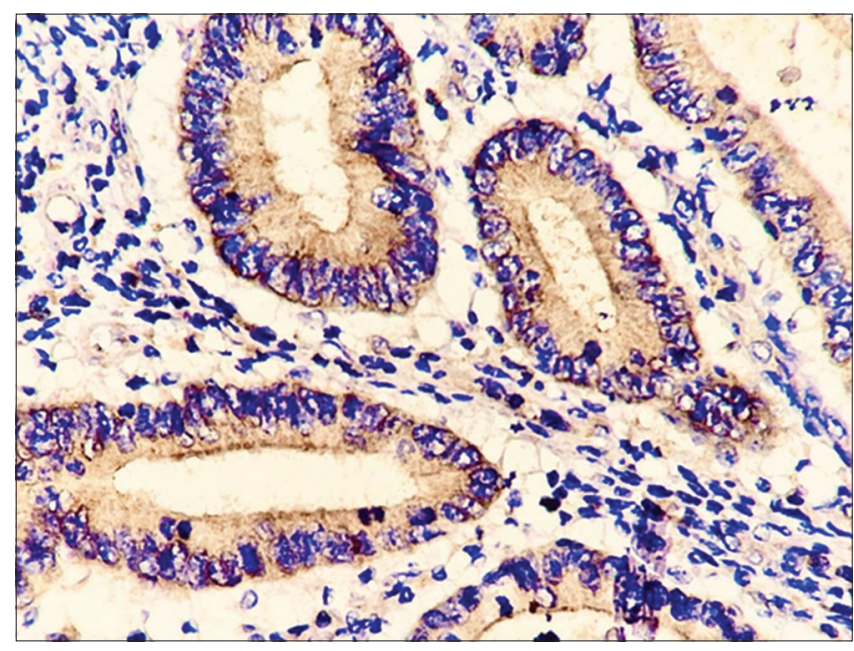

Figure 3: Immunohistochemical staining for CD133 in colorectal cancer samples. High-level CD133 immunoreactivity appears as a dark brown color in the cytoplasm (red arrow), 400× magnification

as IL-6, MFG-E8, IL-11, transforming growth factor- $\beta$, or cells, such as T-helper 2 or regulatory T cells, which may explain the mechanism through which CD163 expression in TAMs can influence protein expression in CS-CRCs. Further studies should explore this mechanism, especially in CRC.

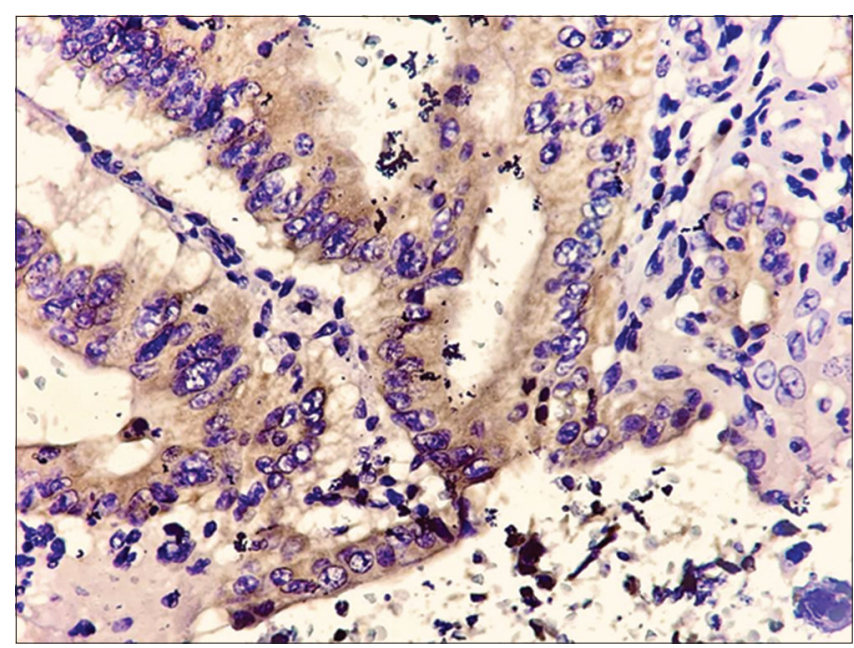

Figure 4: Immunohistochemical CD166 staining in colorectal cancer samples. High-level CD166 immunoreactivity appears as a dark brown color in the cytoplasm (red arrow), 400× magnification 


\section{Conclusion}

We found an association between CD163 expression levels in TAMS and the expression of the CSC markers CD133 and CD166.

\section{References}

1. Granados-Romero JJ, Valderrama-Treviño Al, ContrerasFlores EH, Barrera-Mera B, Enríquez MH, Uriarte-Ruíz K, et al. Colorectal cancer: A review. Int J Res Med Sci. 2017;5(11):466776. http://doi.org/10.3390/ijms18010197 PMid:28106826

2. Siegel RL, Miller KD, Jemal A. Cancer statistics. CA Cancer J Clin. 2015;65(1):5-29. http://doi.org/10.3322/caac.21254 PMid:25559415

3. Prieto-vila M, Takahashi R, Usuba W, Kohama I, Ochiya T. Drug resistance driven by cancer stem cells and their niche. Int J Mol Sci. 2017;18(12):2574. http://doi.org/10.3390/ijms18122574 PMid:29194401

4. Hammond WA, Swaika A, Mody K. Pharmacologic resistance in colorectal cancer: A review. The Adv Med Oncol Rev. 2016;8(1):57-84. http://doi.org/10.1177/1758834015614530 PMid:26753006

5. Humphries HN, Wickremesekera SK, Marsh RW, Brasch HD, Mehrotra S, Tan ST, et al. Characterization of cancer stem cells in colon adenocarcinoma metastasis to the liver. Front Surg. 2018;4:1-76. http://doi.org/10.3389/fsurg.2017.00076 PMid:29404335

6. Wang J, Li D, Cang H, Guo B. Crosstalk between cancer and immune cells: Role of tumor associated macrophages in the tumor microenvironment. Cancer Med. 2019;8:4709-21. http:// doi.org/10.1002/cam4.2327

PMid:31222971

7. Liu J, Peng C, Yang G, Hu W, Yang X. Distribution pattern of tumor associated macrophages predicts the prognosis of gastric cancer. Oncotarget. 2017;8(54):92757-69. http://doi. org/10.18632/oncotarget.21575

PMid:29190953

8. Irjala $H$, Vaittinen $S$, Huhtinen $H$, Sundstro $J$, Salmi $M$, Ristama R. Type and location of tumor-infiltrating macrophages and lymphatic vessels predict survival of colorectal cancer patients. Int J Cancer Type. 2012;873:864-73. http://doi org/10.1002/ijc.26457

PMid:21952788

9. Pinto ML, Rios E, Durães C, Ribeiro R. The two faces of tumor-associated macrophages and their clinical significance in colorectal cancer. Front Immunol. 2019;10:1875. http://doi. org/10.3389/fimmu.2019.01875 PMid:31481956

10. Biswas SK, Mantovani A. Review Macrophage plasticity and interaction with lymphocyte subsets : Cancer as a paradigm. Nat Immunol. 2010;11(10):889-96. http://doi.org/10.1038/ni.1937 PMid:20856220

11. Qian B, Pollard JW. Review macrophage diversity enhances tumor progression and metastasis. Cell. 2010;141(1):39-51. http://doi.org/10.1016/j.cell.2010.03.014

PMid:20371344
12. Larionova I, Cherdyntseva N, Liu T. Interaction of tumorassociated macrophages and cancer chemotherapy. Oncoimmunology. 2019;8(7):1596004. http://doi.org/10.1080/2 162402X.2019.1596004

PMid:31143517

13. Lin $\mathrm{Y}, \mathrm{Xu} \mathrm{J}$, Lan $\mathrm{H}$. Tumor-associated macrophages in tumor metastasis: Biological roles and clinical therapeutic applications. J Hematol Oncol. 2019;3:76. http://doi.org/10.1186/ s13045-019-0760-3

PMid:31300030

14. Zhang Q, Liu L, Gong C, Shi H, Zeng Y, Wang X. Prognostic significance of tumor-associated macrophages in solid tumor: A meta-analysis of the literature. PLoS One. 2012;7(12):e50946. http://doi.org/10.1371/journal.pone.0050946 PMid:23284651

15. Horst D, Kriegl L, Engel J, Kirchner T, Jung A. Prognostic significance of the cancer stem cell markers CD133, CD44, and CD166 in colorectal cancer. Cancer Invest. 2009;27(8):844-50. http://doi.org/10.1080/07357900902744502 PMid:19626493

16. Lugli A, lezzi G, Hostettler I, Muraro MG, Mele V, Tornillo L, et al. Prognostic impact of the expression of putative cancer stem cell colorectal cancer. Br J Cancer. 2010;103(3):382-90. http://doi.org/10.1038/sj.bjc.6605762

\section{PMid:20606680}

17. Hansen AG, Freeman TJ, Arnold SA, Starchenko A, Jonesparis CR, Gilger MA, et al. Elevated ALCAM shedding in colorectal cancer correlates with poor patient outcome. Cancer Res. 2013;(9):2955-65. http://doi.org/10.1158/0008-5472. CAN-12-2052 PMid:23539446

18. Li X, Bu W, Meng L, Liu X, Wang S, Jiang L. CXCL12/CXCR4 pathway orchestrates CSC-like properties by CAF recruited tumor associated macrophage in OSCC. Exp Cell Res. 2019;378(2):131-8. http://doi.org/10.1016/j.yexcr.2019.03.013 PMid:30857971

19. Plaks V, Kong N, Werb Z. Perspective the cancer stem cell niche: How essential is the niche in regulating stemness of tumor cells? Cell Stem Cell. 2015;16(3):225-38. http://doi. org/10.1016/j.stem.2015.02.015 PMid:25748930

20. Kato $\mathrm{Y}$, Nishihara $\mathrm{H}$, Mohri $\mathrm{H}$, Kanno $\mathrm{H}$, Kobayashi $\mathrm{H}$ Clinicopathological evaluation of cyclooxygenase-2 expression in meningioma: Immunohistochemical analysis of 76 cases of low and high-grade meningioma. Brain Tumor Pathol. 2014;31(1):23-30. http://doi.org/10.1007/s10014-012-0127-8 PMid:23250387

21. Raggi C, Mousa HS, Correnti M, Sica A, Invernizzi P. Cancer stem cells and tumor-associated macrophages: A roadmap for multitargeting strategies. Oncogene. 2015;35(6):671-82. http:// doi.org/10.1038/onc.2015.132 PMid:25961921

22. Caronni N, Savino B, Bonecchi R. Immunobiology Myeloid cells in cancer-related inflammation. Immunobiology. 2015;220(2):249-53. http://doi.org/10.1016/j.imbio.2014.10.001 PMid:25454487

23. Kazama S, Kishikawa J, Kiyomatsu T, Kawai K, Nozawa H Ishihara S. Expression of the stem cell marker CD133 is related to tumor development in colorectal carcinogenesis. Asian J Surg. 2018;41(3):274-8. http://doi.org/10.1016/j.asjsur.2016.12.002 PMid:28190751

24. Corbeil D, Marzesco A, Wilsch-bräuninger M, Huttner WB The intriguing links between prominin-1 (CD133), cholesterolbased membrane microdomains, remodeling of apical plasma membrane protrusions, extracellular membrane 
particles, and (neuro) epithelial cell differentiation. FEBS Lett. 2010;584(9):1659-64.

PMid:20122930

25. Smith NR, Davies PS, Levin TG, Gallagher AC, Keene DR Sengupta SK, et al. Cell adhesion molecule CD166/ALCAM functions within the crypt to orchestrate murine intestinal stem cell homeostasis. Cell Mol Gastroenterol Hepatol. 2016;3(3):389-409. http://doi.org/10.1016/j.jcmgh.2016.12.010 PMid:28462380

26. Maniecki MB, Etzerodt A, Ulhøi BP, Steiniche T, Borre M, Dyrskjøt $\mathrm{L}$, et al. Tumor-promoting macrophages induce the expression of the macrophage-specific receptor CD163 in malignant cells. Int J Cancer. 2012;131(10):2320-31. http://doi. org/10.1002/ijc.27506

PMid:22362417

27. Ayob AZ, Ramasamy TS. Cancer stem cells as key drivers of tumour progression. J Biomed Sci. 2018;25(20):1-18. http://doi. org/10.1186/s12929-018-0426-4 PMid:29506506

28. Owen JL, Mohamadzadeh M. Macrophages and chemokines as mediators of angiogenesis. Front Physiol. 2013;4:159. http://doi. org/10.3389/fphys.2013.00159 PMid:23847541

29. Guo Q, Jin Z, Yuan Y, Liu R, Xu T, Wei H, et al. New mechanisms of tumor-associated macrophages on promoting tumor progression: Recent research advances and potential targets for tumor immunotherapy. J Immunol Res. 2016;2016:9720912. http://doi.org/10.1155/2016/9720912

PMid:27975071

30. Fan F, Wang R, Boulbes DR, Zhang H, Watowich SS, Xia L, et al. Macrophage conditioned medium promotes colorectal cancer stem cell phenotype via the hedgehog signaling pathway. PLoS One. 2018;13(1):e0190070. http://doi.org/10.1371/ journal.pone.0190070

PMid:29293549

31. Jinushi M, Chiba S, Yoshiyama H, Masutomi K, Kinoshita I. Tumor-associated macrophages regulate tumorigenicity and anticancer drug responses of cancer stem/initiating cells. Proc Natl Acad Sci U S A. 2011;108(30):12425-30. http://doi. org/10.1073/pnas.1106645108 PMid:21746895

32. Zhou Q, Peng R, Wu X, Xia Q, Hou J, Ding Y, et al. The density of macrophages in the invasive front is inversely correlated to liver metastasis in colon cancer. J Transl Med. 2010;8(13):1-9. http://doi.org/10.1186/1479-5876-8-13 PMid:20141634

33. Henze A, Mazzone M. The impact of hypoxia on tumorassociated macrophages. J Clin Invest. 2016;126(10):3672-9. http://doi.org/10.1172/JCl84427 PMid:27482883

34. Chen Y, Tan W, Wang C. Tumor-associated macrophagederived cytokines enhance cancer stem-like characteristics through epithelial mesenchymal transition. Onco Targets Ther.
2018;11:3817-26. 10.2147/OTT.S168317

PMid:30013362

35. Hanahan D, Weinberg RA. Biological hallmarks of cancer. In Bast RC, Croce CM, Hait WN, Hong WK, Kufe DW, PiccartGebhrart M, editors. Holland-Frei Cancer Medicine. 9th ed. Hoboken, New Jersey: John Wiley \& Sons, Inc.;2017. p. 1-10

36. Ruslie RH, Darmadi D. Administration of neem (Azadirachta indica A. Juss) leaf extract decreases TNF-a and IL-6 expressions in dextran sodium sulfate-induced colitis in rats. J Adv Vet Anim Res. 2020;7:744-9. http://doi.org/10.5455/ javar.2020.g476

PMid:33409321

37. Ruslie RH, Darmadi D, Siregar GA. The effect of neem (Azadirachta indica) leaf extracts on interleukin-10 expression and histological score in dextran sodium sulfate-induced colitis mice. Open Access Maced J Med Sci. 2020;8:578-82.

38. Oosterling SJ, van der Bij GJ, Meijer GA, Tuk CW, Garderen E, van Rooijen $\mathrm{N}$, et al. Macrophages direct tumour histology and clinicaloutcome in a colon cancer model. J Pathol. 2005;207(2):147-55. http://doi.org/10.1002/path.1830 PMid:16104052

39. Tan SY, Fan Y, Luo HS, Shen ZX, Guo Y, Zhao LJ. Prognostic significance of cell infiltrations of immunosurveillance in colorectal cancer. World J Gastroenterol. 2005;11(8):1210-4. http://doi.org/10.3748/wjg.v11.i8.1210

PMid:15754407

40. Forssell J, Oberg A, Henriksson ML, Senling R, Jung A, Palmqvist R. High macrophage infiltration along the tumor front correlates with improved survival in colon cancer. Clin Cancer Res. 2007;13(5):1472-9. http://doi.org/10.1158/1078-0432. CCR-06-2073

PMid:17332291

41. Bacman D, Merkel S, Croner R, Papadopoulos T, Brueckl W, et al. TGFbeta receptor 2 downregulation in tumour-associated stroma worsens prognosis and high-grade tumours show more tumour-associated macrophages and lower TGF-beta1 expression in colon carcinoma: A retrospective study. BMC Cancer. 2007;7:156. http://doi.org/10.1186/1471-2407-7-156 PMid:17692120

42. Koelzera VH, Canonica K, Dawsona H, Sokol L, KaramitopoulouDiamantisa E, Luglia A, et al. Phenotyping of tumor-associated macrophages in colorectal cancer: Impact on single cell invasion (tumor budding) and clinicopathological outcome. Oncoimmunology. 2016;5(4):e1106677. http://doi.org/10.1080/ 2162402X.2015.1106677 PMid:27141391

43. Khorana AA, Ryan CK, Cox C, Eberly S, Sahasrabudhe DM Vascular endothelial growth factor, CD68, and epidermal growth factor receptor expression and survival in patients with Stage II and Stage III colon carcinoma: A role for the host response in prognosis. Cancer. 2003;97(4):960-8. http://doi.org/10.1002/ cncr.11152

PMid:12569594 